\title{
Sosialisasi Istilah Bidang Teknologi dalam Bahasa Indonesia Baku dan Penerapannya di Ruang Publik
}

\author{
Faridatun Nida \\ Program Studi Bahasa Inggris, Universitas Amikom Purwokerto, Indonesia \\ Email: faridatun.nida@amikompurwokerto.ac.id
}

\section{INFORMASI ARTIKEL}

\section{Data artikel:}

Naskah masuk, 12 Oktober 2020

Direvisi, 22 Desember 2020

Diterima, 25 Desember 2020

\section{Kata Kunci:}

Socialization, Technology term, Standard Indonesian

\begin{abstract}
ABSTRAK
Abstract- As a technology-based educational institution, Universitas Amikom Purwokerto is regarded as a group of public agent with high frequency in the use of terms technology. A survey showed that dominancy of English language in terms of technology and the lack of knowledge about its equivalent terms in Indonesian language causes a phenomenon of language mixing in its campus. It leads to a concern about the preservation of Indonesian language. Hence, community service activity entitle Sosialisasi Istilah Bidang Teknologi dalam Bahasa Indonesia Baku is held as an attempt to solve the problem. This event is done by lecture method, that is the issue of language phenomenon is delivered to the students of Universitas Amikom Purwokerto to grow up their motivation in using the equivalent term of technology in Bahasa. There is also an acknowledgement of an application namely Seranai Padanan Asing Indonesia. Practice method is involved in doing the event to give them training in using the application and its features. The activity is expected to optimize its usage in finding the equivalent term of technology in Bahasa so that it can minimize the use of foreign language, especially in formal communication, both spoken and written. They are also doing a practice that is applying the term they found in SPAI in a context of sentence since the terms are created in various part of speech. The enthusiasm of participants during the activity is expected to give spirit in applying the term so that they are directly support the preservation of Indonesian language through their field.
\end{abstract}

Abstrak- Sebagai institusi pendidikan berbasis teknologi,
Universitas Amikom Purwokerto merupakan salah satu wadah
agen masyarakat yang berfrekuensi cukup tinggi dalam
penggunaan istilah-istilah teknologi. Sebuah survei singkat
menunjukkan dominasi bahasa inggris pada istilah teknologi
serta kurangnya pengetahuan terhadap padanan istilahnya
dalam bahasa Indonesia menyebabkan terjadinya percampuran
bahasa. Hal tersebut dipandang cukup mengkhawatirkan karena
dapat mengancam kelestarian bahasa Indonesia. Kegiatan
pengabdian masyarakat berjudul Sosialisasi Istilah Bidang
Teknologi dalam Bahasa Indonesia diadakan sebagai upaya
dalam menanggulangi hal tersebut. Kegiatan dilakukan dengan
menggunakan metode ceramah, yaitu mahasiswa diberikan
pengetahuan mengenai isu-isu kebahasaan terkini untuk




\section{Korespondensi:}

menumbuhkan motivasi peserta agar menggunakan padanan istilah teknologi berbahasa Indonesia. Dalam kegiatan tersebut juga dilakukan pengenalan aplikasi Seranai Padanan Asing Indonesia. Metode praktik dilibatkan dalam pelatihan penggunaan aplikasi beserta fiturnya. Praktik tersebut diharapkan dapat mengoptimalisasi pemanfaatannya dalam mengetahui padanan istilah teknologi dalam bahasa Indonesia, sehingga dapat meminimalisir penggunaan bahasa asing, khususnya dalam komunikasi konteks formal, baik secara lisan maupun tertulis. Mereka juga melakukan praktik penerapan istilah yang ditemukan dalam aplikasi SPAI dalam konteks sebuah kalimat mengingat istilah bidan teknologi muncul dalam beragam kelas kata. Antusiasme yang ditunjukkan oleh para peserta selama mengikuti kegiatan diharapkan dapat membantu pengaplikasian padanan tersebut, sehingga para peserta secara langsung turut mendukung upaya pelestarian bahasa Indonesia.

\section{Faridatun Nida}

Program Studi Bahasa Inggris, Universitas Amikom Purwokerto

Jl. Let. Jend. Pol. Soemarto, Purwanegara, Purwokerto Utara, Banyumas, Indonesia

\section{PENDAHULUAN}

Perkembangan teknologi memberikan dampak terhadap bahasa penggunanya. Salah satu dampaknya terlihat dari keterbaruan kosakata (Octavia \& Hayati, 2020). Kosakata berupa istilah - istilah dalam bidang teknologi bermunculan dan secara dominan menggunakan bahasa Inggris (Susanti, 2016). Dominasi peranan bahasa tersebut menjadikannya dikenal sebagai bahasa ilmu pengetahuan dan teknologi (Foyewa, 2015). Selain dianggap sebagai bahasa Internasional, teknologi tercetus dan banyak berkembang di negara-negara berbahasa Inggris.

Penggunaan istilah berbahasa Inggris terjadi dan tersebar seiring dengan penyebaran produk berteknologi tersebut. Keadaan tersebut menyebabkan bahasa lain, yang belum memiliki padanan untuk istilah yang digunakan, memilih untuk mengaplikasikan istilah berbahasa asing tersebut. Alhasil, bahasa yang digunakan pun bercampur. Hal inilah yang terjadi pada bahasa Indonesia.

Indonesia merupakan sebuah negara dengan bahasa nasionalnya yaitu bahasa
Indonesia, seperti yang tertuang dalam Perpres No. 63 tahun 2019. Bahasa tersebut juga dianggap sebagai bahasa pemersatu bangsa sebagaimana diilhami dari isi Sumpah Pemuda serta menjadi jati diri bangsa Indonesia (Arifin, 2015). Dengan demikian, bahasa Indonesia tidak hanya digunakan sebagai bahasa komunikasi, tetapi juga memberikan makna tersendiri bagi para penggunanya, khususnya penutur asli bahasa Indonesia.

Sebagai salah satu negara penerima dan pengguna teknologi, Indonesia tentu belum sepenuhnya memiliki padanan untuk setiap istilah teknologi berbahasa asing. Hal tersebut membuatnya menggunakan istilah berbahasa asing yang telah tersedia. Padahal dalam UU No. 24 tahun 2009 pasal 26 ayat 3 disebutkan bahwa bahasa Indonesia wajib digunakan untuk produk yang beredar di Indonesia, baik yang berasal dari dalam dan luar negeri (A, 2018).

Dominasi penggunaan istilah bahasa asing secara berlebihan dalam bahasa Indonesia dianggap sebagai sebuah sikap penjajahan terhadap suatu bahasa (Pastika, 2012). Selain 
itu, campur aduknya bahasa yang digunakan dikhawatirkan dapat menimbulkan permasalahan kebahasaan yang lebih besar seperti hilangnya identitas bahasa dan menurunnya penggunaan kosa kata berbahasa Indonesia yang lain dikarenakan tergantikan oleh bahasa Inggris yang lebih berelasi dengan istilah berteknologi tersebut. Kesan kebakuan bahasa pun dapat menjadi menurun. Kekhawatiran tersebut juga muncul terkait isu kepunahan bahasa yang telah terjadi, baik di dalam maupun di luar negeri.

Badan Bahasa di bawah Kementerian Pendidikan dan Kebudayaan melakukan beberapa langkah guna menjaga kelestarian bahasanya. Dalam artikelnya yang diterbitkan secara online (Maulipaksi, 2017), kemendikbud aktif melakukan sosialisasi penggunaan bahasa Indonesia di ruang publik. Sosialisasi juga dilakukan di beberapa daerah di Indonesia, seperti Papua (Yapen, 2019), Jawa Timur, Jawa Barat (Admin, 2019), dan Kalimantan Barat.

Sosialisasi dilakukan guna mendukung pelestarian bahasa (Hanung, 2019) dan memaksimalkan penggunaan bahasa Indonesia di ruang publik. Terlebih terdapat wacana yang menyatakan bahwa bahasa Indonesia berpeluang menjadi bahasa yang digunakan dalam rapat di PBB atau perkumpulan internasional lainnya.

Badan bahasa juga mengadakan pertemuan, seperti seminar dan lokakarya, yang diadakan sebagai sebuah ajang bagi para peneliti untuk menyuarakan atau bertukar informasi mengenai hasil penelitian yang telah dilakukannya terkait dengan penggunaan bahasa di ruang publik. Dalam penelitian tersebut, mereka juga turut mendukung upaya himbauan kepada masyarakat untuk menggunakan bahasa Indonesia.

Selain melakukan sosialisasi dan menggelar pertemuan ilmiah, langkah lain yang ditempuh sebagai upaya internasionalisasi bahasa Indonesia ditengah era globalisasi adalah dengan memberikan padanan (Annisa, 2019; Hudaa, 2019). Hingga saat ini, beberapa padanan untuk istilah teknologi berbahasa asing. telah terlahir dan ditetapkan untuk digunakan dalam bahasa Indonesia. Padanan umumnya merupakan hasil serapan dari bahasa asingnya melalui proses adaptasi, adopsi, penerjemahan, dan kreasi (Baharman, 2012). Beberapa padanan dihasilkan dari saran pengguna bahasa Indonesia.

Padanan diorganisir dan dipublikasikan melalui aplikasi Senarai Padanan Istilah Asing (SPAI). Aplikasi tersebut dapat diakses secara bebas dan terbuka oleh seluruh pengguna internet dengan mengunjungi laman daring Badan Pengembangan dan Pembinaan Bahasa, Kementrian dan Kebudayaan Republik Indonesia. Penyediaan istilah juga tidak terbatas hanya pada istilah bidang teknologi, namun juga bidang lain yang terdapat istilah bahasa Inggris.

Penyediaan padanan melalui laman Badan Bahasa diharapkan dapat dimanfaatkan dengan baik, khususnya oleh para penutur asli bahasa Indonesia dan penutur asing berbahasa Indonesia. Pada kenyataannya, pemanfaatan belum secara maksimal dilakukan. Keterbaruan padanan yang disediakan oleh Balai Bahasa belum banyak diketahui oleh pengguna bahasa Indonesia. Hal tersebut menimbulkan adanya kebutuhan untuk memberikan sosialisasi terhadap istilah tersebut sehingga dapat mengoptimalkan penerapan bahasa baku berbahasa Indonesia.

Universitas Amikom Purwokerto merupakan perguruan tinggi dengan tingkat penggunaan istilah - istilah teknologi berfrekuensi cukup sering. Hal tersebut terbukti nyata terutama dalam proses pembelajaran. Banyak kosakata istilah teknologi berbahasa asing yang muncul sebagai akibat dari asal mula terciptanya istilah tersebut. Dalam penugasannya berupa penulisan formal akademik seperti skripsi dan laporan tugas perkuliahan, istilah teknologi berbahasa asing juga banyak disebutkan. 
Percampuran bahasa mungkin tidak akan menghilangkan bahasa Indonesia seluruhnya, tetapi dapat mengubah makna, nilai dan kesopanannya (Azizah, 2019). Banyaknya penggunaan bahasa asing dalam istilah teknologi mengurangi kesan keindonesiaan terhadap bahasa yang digunakan. Padahal padanan istilahnya dalam bahasa Indonesia mulai disediakan. Fenomena ini memberikan indikasi bahwa pengetahuan mengenai padanan istilah teknologi dalam bahasa Indonesia bahasa baku belum maksimal. Selain itu, penerapannya pun masih belum optimal. Demi mendukung terciptanya penggunaan bahasa baku di ruang publik, maka universitas tersebut, khususnya dalam hal ini adalah mahasiswa, dianggap dapat menjadi sasaran yang tepat untuk diadakan sosialisasi.

Kegiatan sosialisasi dilakukan dengan memanfaatkan teknologi, yaitu melibatkan aplikasi bernama Seranai Padanan Istilah Asing yang dapat diakses melalui laman daring Google atau penyedia peramban lainnya (Wanti \& Tripustikasari, 2019). Mahasiswa disinyalir belum mengetahui keberadaan aplikasi tersebut, sehingga kegiatan yang disusun akan meliputi agenda pengenalan aplikasi tersebut dan praktiknya yang langsung dilakukan oleh para peserta. Diharapkan melalui kegiatan yang dilaksanakan, padanan istilah teknologi dapat diaplikasikan dalam komunikasi sehari - hari, khususnya dalam penulisan skripsi dan penulisan formal akademik lainnya.

\section{METODE PELAKSANAAN}

Berdasarkan rumusan masalah yang dipaparkan pada bagian pendahuluan, maka disusunlah sebuah kegiatan pengabdian masyarakat berjudul "Sosialisasi Istilah Bidang Teknologi dalam Bahasa Indonesia Baku dan Penerapannya di Ruang Publik. Kegiatan dilakukan melalui tiga tahap.

Tahap pertama yaitu persiapan. Tahap ini dilakukan dengan metode observasi, yaitu melakukan pengamatan terhadap mitra.
Dilakukan survei singkat terkait penggunaan bahasa Indonesia baku khususnya mengenai istilah bidang teknologi. Penggunaan istilah teknologi di lingkungan Universitas Amikom secara dominan masih menggunakan bahasa asing. Hal tersebut dimaklumi mengingat konsentrasi kampus tersebut lebih diutamakan kepada teknologi dan kurangnya pengetahuan atau informasi dalam bidang kebahasaan. Dengan demikian permasalahan ini menjadi bekal atau landasan permasalahan yang perlu untuk diatasi.

Dalam tahap persiapan juga dipertimbangkan sasaran peserta kegiatan. Melalui berbagai pertimbangan, maka peserta difokuskan pada mahasiswa aktif Universitas Amikom Purwokerto. Pemilihan peserta tersebut juga dilakukan agar capaian kegiatan sesuai dengan harapan. Sebagai mahasiswa dengan latar belakang pendidikan berfokus pada bidang teknologi, maka produktifitas dan penggunaan istilah teknologi sangat dominan. Dengan mempertimbangkan dominasi bahasa Inggris dalam penciptaan istilah bidang teknologi dan upaya pemerintah dalam usaha pelestarian bahasa, maka para peserta dianggap perlu untuk mendapatkan pengetahuan tambahan mengenai ilmu bahasa, khususnya dalam hal ini terealisasi dalam penggunaan padanan istilah bahasa asing dalam komunikasinya di lingkungan akademik.

Sebelum pelaksanaan, dilakukan juga permohonan ijin terkait penyelenggaraan kegiatan kepada pihak - pihak yang bersangkutan. Kegiatan dilaksanakan di UPT Bahasa Universitas Amikom Purwokerto. Hal tersebut dilakukan dengan menimbang sasaran kegiatan yaitu mahasiswa aktif Universitas Amikom Purwokerto. Keterbatasan ruang disertai dengan aturan protokol kesehatan Covid-19 menjadi bahan pertimbangan untuk membatasi jumlah peserta, yaitu 15 orang.

Selanjutnya, merumuskan langkah langkah yang tepat guna mengatasi permasalahan yang ditemukan. Pelaksana kegiatan mencoba mencari solusi yang juga 
berhubungan dengan dunia target sasaran sosialisasi. Solusi tersebut berupa pemanfaatan sebuah aplikasi atau fitur dalam suatu halaman web berjudul Senarai Padanan Asing Indonesia di Ruang Publik. Penyampaian materi difokuskan pada bentuk aplikasi yang dapat diakses melalui laman Badan Pengembangan dan Pembinaan Bahasa dengan mempertimbangkan keterbaruan aplikasi atau fitur di dalamnya.

Tahap kedua yaitu pelaksanaan. Langkah - langkah yang telah dirumuskan kemudian diterapkan pada saat pelaksanaan kegiatan. Kegiatan dilakukan dengan metode ceramah, yaitu diawali dengan presentasi berisi pendahuluan sebagai gambaran mengenai kegiatan yang akan dilakukan, termasuk alasan dan manfaatnya. Kegiatan juga diisi dengan diskusi dan simulasi aplikasi pendukungnya. Pelaksanaan juga dilakukan dengan metode praktik, yaitu para peserta secara langsung mempraktikan penggunaan aplikasi beserta penerapan istilah yang ditemukan dalam aplikasi tersebut dalam konteks kalimat.

Tahap ketiga yaitu evaluasi. Pada tahap ini dikaji ulang mengenai kegiatan yang telah dilaksanakan untuk selanjutnya melihat kemungkinan keberlanjutannya setelah kegiatan tersebut. ditemukan

\section{HASIL DAN PEMBAHASAN}

Kegiatan pengabdian masyarakat berjudul "Sosialisasi Istilah Bidang Teknologi dalam Bahasa Indonesia Baku dan Penerapannya di Ruang Publik" dilaksanakan pada hari Kamis tanggal 24 September 2020.

Bertempat di UPT Bahasa Universitas Amikom, para peserta diberikan wawasan mengenai pentingnya menggunakan bahasa Indonesia dengan baik dan benar, termasuk menerapkan padanan istilah berbahasa asing yang tersedia dalam bahasa Indonesia. Hal tersebut dilakukan guna memberikan pemahaman kepada para peserta mengenai pentingnya kegiatan yang dilaksanakan.

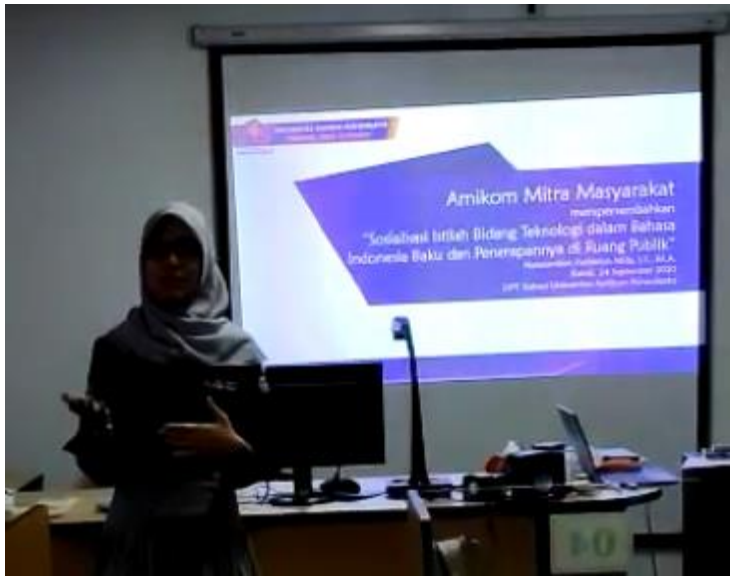

Gambar 1. Proses Pengenalan Materi Sosialisasi

Diberikan juga gambaran fenomena kebahasaan yang terjadi di sekitar kita, seperti kepunahan bahasa serta faktor penyebabnya (Azis, Mahyuni, Syahdan, \& Yusra, 2019), diskontinuitas bahasa (Zalwia, Moita, \& Upe, 2018), termasuk kepunahan yang terjadi di dunia pada Bahasa Gelstach. Bahasa tersebut mengalami kepunahan dikarenakan kurangnya kesadaran penutur asli untuk menggunakan bahasa tersebut. Masyarakat cenderung menggunakan bahasa lain, yaitu bahasa Inggris. Selain secara internasional, diberikan juga informasi mengenai kepunahan bahasa daerah di Indonesia. Hal tersebut terjadi di Indonesia bagian timur, khususnya Papua. Beberapa bahasa di Papua dikategorikan menuju kepunahan disebabkan oleh semakin berkurangnya penutur bahasa tersebut. Masyarakat cenderung menggunakan bahasa Indonesia.

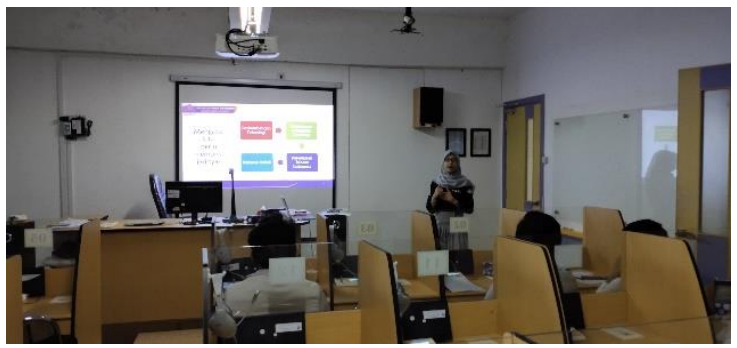

Gambar 2. Proses Penyampaian Materi Sosialisasi

Pemaparan mengenai fenomena kepunahan bahasa dianggap cukup penting mengingat para peserta diindikasikan belum banyak mengetahui isu-isu yang berkaitan dengan kebahasaan. Selain itu, fenomena 
tersebut juga diharapkan dapat memotivasi dan menumbuhkan semangat para peserta untuk melestarikan bahasa yang ada, baik bahasa nasional, bahasa Indonesia, maupun bahasa daerah (Susiati, 2020). Dengan demikian, mereka menggunakan dan menerapkan bahasa Indonesia dengan tepat dan sesuai di ruang publik, khususnya dalam hal penulisan formal akademis.

Selanjutnya, peserta diberikan pre-tes. Ditampilkan beberapa padanan istilah dalam bidang teknologi. Para peserta diminta untuk menebak padanannya yang sudah lebih dahulu familiar dalam bahasa Inggris. Hasil menunjukkan bahwa tidak banyak kosakata tertampil yang diketahui oleh para peserta. Hal tersebut menunjukkan kurangnya pengetahuan para peserta terhadap padanan istilah yang telah tersedia.

Berangkat dari permasalahan di atas, kegiatan berikutnya adalah memberikan solusi mengenai cara mengetahui jawab dari padanan tersebut yaitu memperkenalkan sebuah aplikasi bernama Seranai Padanan Istilah Asing.

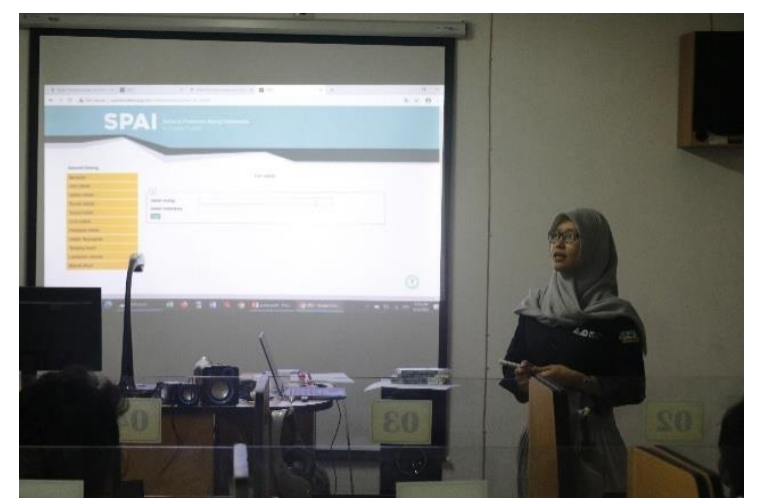

Gambar 3. Pengenalan terhadap Aplikasi SPAI

Seranai Padanan Istilah Asing (SPAI) merupakan sebuah aplikasi berbasis internet yang diluncurkan oleh badan bahasa di bawah Kementrian Pendidikan dan Kebudayaan sebagai salah satu upaya dalam menjaga kelestarian bahasa Indonesia. Sifat bahasa yang dinamis ditunjukkan dengan memberikan padanan terhadap kosakata baru berbahasa asing. Hal inilah yang menjadi maksud dari diluncurkannya SPAI. Aplikasi tersebut dapat diakses melalui peramban Google dengan terlebih dahulu mengunjungi laman daring balai bahasa. Pada laman tersebut, tersedia beberapa fitur aplikasi, salah satunya adalah Seranai Padanan Asing Indonesia (SPAI).

Pada layar tampilan presentasi, kegiatan tidak langsung diarahkan pada simulasi, melainkan pengenalan terlebih dahulu terhadap aplikasi yang digunakan. Penjelasan kepada mahasiswa dilakukan agar mereka memahami fungsi dan manfaat dari aplikasi. Kebermanfaatnnya kemudian diharapkan menjadi solusi dari permasalahan yang diuraikan.

SPAI merupakan sebuah fitur yang dapat diakses melalui laman daring Badan Pengembangan dan Pembinaan Bahasa Kementerian Pendidikan dan Kebudayaan Republik Indonesia. SPAI juga ditemukan berupa aplikasi yang dapat diunduh melalui layanan AppStore pada gawai berbasis android. Aplikasi tersebut dapat dimanfaatkan untuk mengetahui padanan istilah teknologi yang dikenal menggunakan bahasa asing, yaitu bahasa Inggris. Padanan dapat dicari langsung melalui fitur pencarian. Istilah juga ditemukan telah terkelompok dengan rapi yang dapat dilihat melalui menu daftar istilah. Pada menu tersebut tertampil beberapa bidang yang merupakan kategori dari pengelompokan

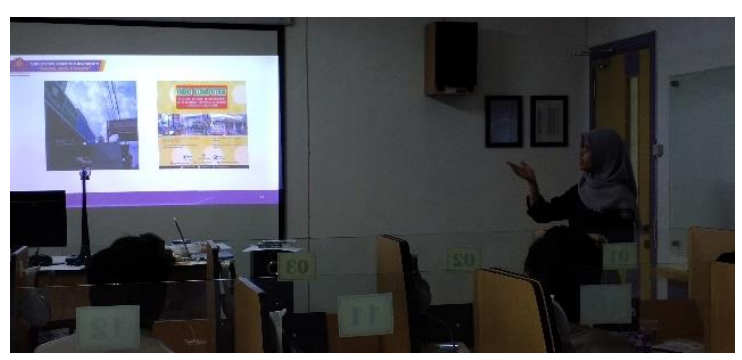

istilah asing.

Gambar 4. Pemaparan mengenai Gambaran Penggunaan Istilah Teknologi di Ruang Publik

Pemaparan dilanjutkan dengan melihat penggunaan bahasa Indonesia dan bahasa Asing di ruang publik, khususnya mengenai penggunaan istilah - istilah berbahasa Inggris. Pada layar presentasi ditampilkan beberapa contoh gambar yang mengandung contoh 
penggunaan bahasa Indonesia dan bahasa asing di ruang publik Para peserta diminta untuk memberikan pendapatnya mengenai hal tersebut.

Di akhir pemaparan, peserta diminta menebak kembali istilah-istilah yang ditampilkan di layar presentasi. Beberapa menjawab dengan tepat. Hal tersebut menunjukkan bahwa pengetahuan mereka telah meningkat melalui pemanfaatan SPAI.

Selain itu diberikan juga gambaran mengenai penerapan istilah tersebut dalam suatu teks. Teks diambil dari majalah dan koran. Melalui penggambaran tersebut diharapkan para peserta memiliki gambaran mengenai penerapan padanan istilah tersebut. berkaitan dengan indikator keberhasilan, dilakukan juga pengujian. Para peserta diminta untuk menemukan padanan suatu istilah dan menerapkannya dalam suatu susunan kalimat.

Simulasi dilakukan untuk mengetahui prosedur penggunaan Senarai Padanan Asing Indonesia. Para peserta mempraktikkan penggunaan fitur SPAI yang tersedia di laman badan bahasa tersebut. Mereka juga dikenalkan fitur-fitur pundukung didalamnya serta fungsi dan isi dari SPAI. Tidak ditemukan kendala yang berarti dalam simulasi tersebut dikarenakan latar belakang para peserta dan kesehariannya yang berkaitan erat dengan bidang teknologi.

Setelah diberikan simulasi mengenai penggunaan aplikasi tersebut, peserta diminta untuk menerapkan istilah - istilah bahasa asing dan padanan yang ditemukan dalam SPAI untuk diilustrasikan penggunaannya dalam konteks kalimat.

Setelah berhasil merangkai sebuah kalimat. selanjutnya peserta diminta untuk menuliskannya dalam di papan tulis yang tersedia. Hal tersebut dilakukan untuk mengoreksi pekerjaan mereka secara bersamasama sehingga jika ditemukan kesalahan, maka peserta dapat mengetahui cara untuk memperbaikinya. Mayoritas peserta sudah melakukannya dengan benar. Penulisan dan penerapannya dilakukan dengan tepat sesuai dengan fungsinya pada kalimat. Meningkatnya pengetahuan dan keahlian dalam menggunakan istilah - istilah teknologi dalam bahasa Indonesia baku menjadi salah satu indikator

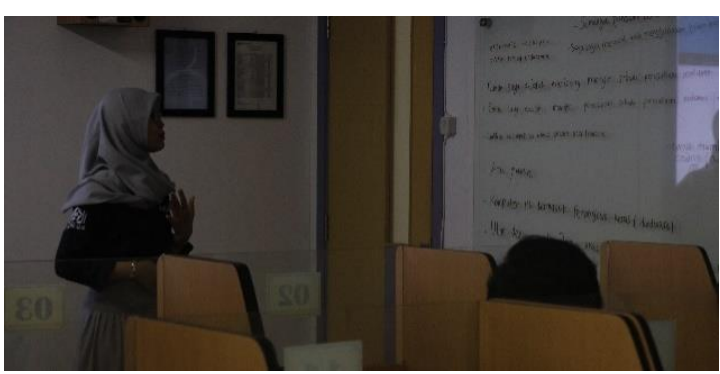

keberhasilan kegiatan yang dilaksanakan.

Gambar 5. Review Hasil Pekerjaan Para Peserta

Sebagai bentuk apresiasi, 3 peserta terbaik yang mengikuti kegiatan dan menyusun kalimat dengan menarik diberi kenangkenangan. Diharapkan mereka akan mengingat kegiatan tersebut dan menerapkan ilmu yang sudah didapatkan dengan baik.

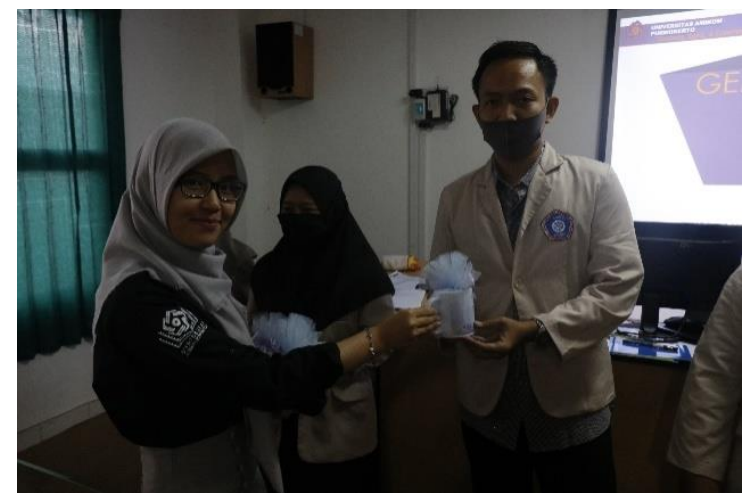

Gambar 6. Pemberian Hadiah kepada Para Peserta dengan Hasil Terbaik

\section{KESIMPULAN}

Berdasarkan hasil pembahasan mengenai kegiatan yang telah dilakukan, maka dapat disimpulkan bahwa kegiatan telah berhasil dilaksanakan. Seluruh peserta berhasil mengikuti kegiatan dengan baik. Indikator keberhasilan kegiatan pun tercapai. Hal tersebut dikarenakan latar belakang peserta yang memang bergelut dibidang teknologi, sehingga pengoperasian aplikasi pun tidak sulit dilakukan. Para peserta juga mendapatkan wawasan baru mengenai kebahasaan yang 
dapat dimanfaatkan dan diterapkan dalam keahlian menulis yang mereka miliki. 'penggunaan SPAI juga diharapkan dapat mendukung kualitas penulisan dan pelestarian bahasa Indonesia baku.

Kendala dari kegiatan ini adalah keterbatasan waktu dan tempat serta jumlah peserta dikarenakan kegiatan tersebut dilaksanakan pada masa pandemi virus corona covid-19. Guna keberlangsungan acara, maka kegiatan dilakukan sesuai dengan protokol kesehatan yang berlaku. Para peserta juga menggunakan masker selama kegiatan berlangsung.

Menimbang manfaat yang didapatkan dengan diadakannya kegiatan tersebut, maka kegiatan rencananya akan kembali diadakan dengan sasaran yang lebih spesifik dan keluaran yang lebih nyata sebagai hasil pencapaian kegiatan.

\section{UCAPAN TERIMA KASIH}

Ucapan terimakasih ditujukan kepada Amikom Mitra Masyarakat yang telah mendukung acara tersebut melalui pembiayaan yang disediakan. Terima kasih juga diucapkan kepada Universitas Amikom Purwokerto, khususnya Unit Pelayanan Terpadu (UPT) Bahasa, yang telah mendukung kegiatan ini dengan kesediaanya memberikan tempat untuk dilangsungkannya kegiatan pengabdian.

\section{DAFTAR PUSTAKA}

A, F. (2018). Penggunaan Bahasa Indonesia Pada Media Ruang Publik Di Kota Pekanbaru. Suar Betang, 13(2), 131-144. https://doi.org/10.26499/surbet.v13i2.76

Admin. (2019). Penyuluhan Penggunaan Bahasa Ruang Publik Di Kabupaten Indramayu - Balai Bahasa Jawa Barat. Balai Bahasa Jawa Barat.

Annisa, P. (2019). Pengaruh Bahasa Asing terhadap Bahasa Indonesia di Tengah Arus Globalisasi. Universitas Sebelas Maret, (36).

Arifin, M. (2015). Mempertahankan Bahasa Indonesia Sebagai Jati Diri Bangsa. Prosiding Seminar Nasional Bulan
Bahasa UNIB, Prosiding, 82-87.

Azis, A. D., Mahyuni, M., Syahdan, S., \& Yusra, K. (2019). Faktor-Faktor Penyebab Kepunahan Bahasa Daerah Di Tanah Rantau. Jurnal Sosial Ekonomi Dan Humaniora, 5(1), 1-7. https://doi.org/10.29303/jseh.v5i1.27

Azizah, A. R. (2019). Penggunaan Bahasa Indonesia dan Bahasa Gaul di Kalangan Remaja. Jurnal Skripta, 5(2), 33-39.

Baharman. (2012). Penguatan Bahasa Indonesia Melalui Penyerapan Dan Pemadanan Istilah Asing Pada Surat Kabar Baharman. Kongres Bahasa Indonesia, (1), 1-22.

FOYEWA, R. A. (2015). English: The International Language Of Science And Technology. Ekp, 3(5), 34-41.

Hanung, E. (2019). Mempertahankan Bahasa Indonesia Di Era Globalisasi. Research Gate.

https://doi.org/10.31227/osf.io/tv27r

Hudaa, S. (2019). Transliterasi, Serapan, dan Padanan Kata: Upaya Pemutakhiran Istilah dalam Bahasa Indonesia. SeBaSa, 2(1), 1-6.

Maulipaksi, D. (2017). Utamakan Bahasa Indonesia, Lestarikan Bahasa Daerah, dan Kuasai Bahasa Asing. Kementrian Pendidikan Dan Kebudayaan.

Octavia, W., \& Hayati, N. (2020). Pola Karakteristik Ragam Bahasa Istilah Pada Masa Pandemi COvid 19 (Coronavirus Disease 2019). Tabasa: Jurnal Bahasa, Sastra, Dan Pengajarannya, 1(1), 1-15.

Pastika, I. W. (2012). Pengaruh Bahasa Asing terhadap Bahasa Indonesia dan Bahasa Daerah: Peluang atau Ancaman? Jurnal Kajian Bali (Journal of Bali Studies), 2(2), 141-164.

Susanti, E. (2016). Glosarium Kosakata Bahasa Indonesia Dalam Ragam Media Sosial. Dialektika, 3(24), 229-250.

Susiati, S. (2020). Pentingnya Melestarikan Bahasa Daerah. Research Gate, (March). https://doi.org/10.31228/osf.io/wk8xm

Wanti, L. P., \& Tripustikasari, E. (2019). Pelatihan Komputer Dasar Bagi Kader PKK dan Posyandu Di Desa Patikraja. Madani: Indonesian Journal of Civil Society, 1(1), 17-23. https://doi.org/10.35970/madani.v1i1.22

Yapen, T. L. H. (2019). Balai Bahasa Papua 
Sosialisasi Penggunaan Bahasa Indonesia Di Luar Ruangan - Kabupaten Kepulauan Yapen. Kabupaten Kepulauan Yapen.

Zalwia, Z., Moita, S., \& Upe, A. (2018). Modernisasi dan Diskontinuitas Bahasa Daerah. Neo Societal, 3(2), 494-502. 